\title{
Anti-carcinogenic properties of omeprazole against human colon cancer cells and azoxymethane-induced colonic aberrant crypt foci formation in rats
}

\author{
JAGAN M.R. PATLOLLA ${ }^{1}$, YUTING ZHANG ${ }^{1}$, QIAN LI ${ }^{1}$, VERNON E. STEELE ${ }^{2}$ and CHINTHALAPALLY V. RAO ${ }^{1}$ \\ ${ }^{1}$ Center for Chemoprevention and Cancer Drug Development, Department of Medicine, Hem-Onc Section, \\ PC Stephenson Oklahoma Cancer Center, University of Oklahoma Health Sciences Center, Oklahoma City, OK, \\ ${ }^{2}$ Division of Cancer Prevention, National Cancer Institute, Bethesda, MD, USA
}

Received July 20,2011; Accepted August 22, 2011

DOI: 10.3892/ijo.2011.1214

\begin{abstract}
Omeprazole is a proton pump inhibitor, a widely used drug to treat ulcers and gastroesophageal refluxdisease. We have evaluated colon cancer chemopreventive properties of omeprazole using azoxymethane (AOM)-induced colonic aberrant crypt foci (ACF) in male F344 rats and analyzed cell growth inhibition and apoptosis induction in human colon cancer cells. Five-week-old male F344 rats were fed a control or experimental diet containing two doses of omeprazole (200 and $400 \mathrm{ppm})$. After one week, all animals were s.c. injected with $\mathrm{AOM}(15 \mathrm{mg} / \mathrm{kg}$ body weight, once weekly for two weeks). Rats continued on experimental diets for seven more weeks before being sacrificed. Colons were histopathologically evaluated for ACF. Human colon cancer HCT-116 and HCA-7 cells treated with omeprazole were evaluated for different markers associated with proliferation and apoptotic markers using Western blot technique. Rats fed with 200 and 400 ppm of omeprazole significantly suppressed total colonic ACF formation $(\sim 30 \%$, $\mathrm{P}<0.001)$ and showed significant suppression of multi-crypt foci $(\sim 30-50 \%, P<0.05-0.001)$. Omeprazole produced significant dose-response effects on inhibition of multi-crypt foci $(\geq 4)$. Omeprazole treatment in human colon cancer cell lines HCT-116 and HCA-7 cells resulted in induction of $\mathrm{p} 21^{\text {waf1/cip1 }}$ and decreased the expression of anti-apoptotic proteins Bcl-2, $\mathrm{Bcl}-\mathrm{X}_{\mathrm{L}}$ and survivin in a dose-dependent manner. Anticancer properties observed in colon cancer cell lines suggest that
\end{abstract}

Correspondence to: Professor C.V. Rao, 975 NE 10th Street, BRC 1203, OU Cancer Institute/OUHSC, Oklahoma City, OK 73104, USA

E-mail:cv-rao@ouhsc.edu

Abbreviations: ACF, aberrant crypt foci; PPI, proton pump inhibitors; CRC, colorectal cancer; IAP, inhibitors of apoptosis protein; AOM, azoxymethane; GERD, gastroesophageal refluxdisease; MTT, 3-[4,5-dimetylthiazole-2-yl]-2,5-diphenyl tetrazoliumbromide

Key words: aberrant crypt foci, omeprazole, colon cancer, chemoprevention, apoptosis omeprazole may induce key signaling molecules of antiproliferation and inhibition of anti-apoptotic proteins.

\section{Introduction}

Colorectal cancer (CRC) is one of the most common cancers in the Western world and ranks as the third most common cause of death from malignancy (1). Proton pump inhibitors (PPI) are drugs that are largely used for treatment of gastroesophageal refluxdisease (GERD) or for reduction of gastric acid production. Clinically proven and most common PPI are omeprazole, lansoprazole, and esomeprazole, which are widely used as antiulcer drugs and have demonstrated protection against acidrelated diseases (2). They act as potent inhibitors of the gastric acid pump used for short- or long-term treatments without any unwanted side effects $(2,3)$. In addition to inhibition of gastric acid production, proton pump inhibitors have been shown to exert apoptotic properties in human B-cells $(4,5)$ and gastric cancer cell lines (6); as well as induction of growth arrest of colonic cancer cell lines (7). Previous studies have demonstrated anti-inflammatory and cytoprotective actions in gastric mucosal and endothelial cells $(6,8,9)$. Furthermore, in vivo studies support the anticancer properties of omeprazole $(11,12)$. With regard to colon carcinogenesis, Penman et al (10) reported chemopreventive properties of omeprazole treatment reduced colon carcinogenesis in Sprague-Dawley rats. Kim et al (11) reported anti-inflammatory, anti-oxidative, and anti-mutagenic activities of omeprazole in colitis-associated carcinogenesis in mouse models. Omeprazole-induced hyper-gastrinaemia has consistently failed to increase tumor incidence in carcinogen-induced colorectal malignancy in rats $(10,12,13)$. These anti-cancer properties combined with antiulcer activities, and unwanted side effects of omeprazole, justifies further investigations on the chemopreventive properties in well established model of colon cancer to understand the anticancer mechanisms in colon cancer cell lines.

Apoptosis is a process essential for normal development and homeostasis in multicellular organisms and is an important tumor growth regulator. Apoptosis is a complex process regulated by various cellular proteins including $\mathrm{Bcl}-2, \mathrm{Bcl}-\mathrm{X}_{\mathrm{L}}$ $(14,15)$ and inhibitors of apoptosis proteins (IAP) $(16,17)$. 
Survivin is the member of the mammalian inhibitor of apoptosis family, which obstructs the apoptotic signaling cascade by blocking apoptotic activities, and is a critical protein that regulates microtubule dynamics, cell survival, and promotes resistance to therapy $(18,19)$. The most notable feature of survivin expression is its absence in most terminally differentiated normal tissues but it is highly expressed in all types of malignancies $(19,20)$. Survivin is known to be involved in colorectal carcinogenesis and highly expressed in colorectal cancer cells (21-23).

In the present study, we assessed the potential chemopreventive efficacy of omeprazole on azoxymethane induced colon cancer model using ACF as an efficacy marker in male F344 rats. The anti-proliferative and apoptotic properties of omeprazole in HCA-7 and HCT-116 human colon cancer cells were also demonstrated.

\section{Materials and methods}

Animals, care and diets. All animal experiments were performed in accordance with NIH guidelines and the University of Oklahoma Health Sciences Center Institutional Animal Care and Use Committee (IACUC) approved protocols. Six-weekold male F344 rats were obtained from Harlan Laboratories (Indianapolis, IN) and housed in ventilated cages with a 12-h light/dark cycle in the rodent barrier facility. Temperature and relative humidity were controlled at $21^{\circ} \mathrm{C}$ and $55 \%$, respectively. All rats were acclimatized to the above conditions for one week with free access to standard laboratory rodent chow and drinking water until initiation of the experiment. Animals were cared for according to the American Council on Animal Care guidelines. Diets were based on modified AIN-76A containing 5\% corn oil by weight (24) and all diet ingredients were procured from Bioserv (Frenchtown, NJ). Omeprazole (Fig. 1) was provided by the National Cancer Institute chemopreventive drug repository (Rockville, MD). The experimental diets containing $0.02 \%$ (200 ppm) and $0.04 \%$ (400 ppm) omeprazole were prepared once a week and stored at $-4^{\circ} \mathrm{C}$. Rats were allowed ad libitum access to the respective diets and tap water.

In vivo efficacy study. Rats at seven weeks of age were randomized into groups either receiving the control diet or diets containing 200 and 400 ppm omeprazole (n=16 rats/group; 10 rats AOM-treated and 6 rats vehicle-treated). Rats remained on control or experimental diets until termination. At eight weeks of age, rats intended for carcinogen treatment were s.c. injected with AOM once a week for two weeks at a dosage of $15-\mathrm{mg} / \mathrm{kg}$ body weight. Rats intended for vehicle treatment were given s.c. $0.2 \mathrm{ml}$ of normal saline. All animals were sacrificed by $\mathrm{CO}_{2}$ asphyxiation 8 weeks after AOM-injection. Colons were removed, flushed with ice-cold $\mathrm{PBS}$, and slit open along the length from the anus to the cecum. Colons were assessed for any macroscopic changes and were fixed flat between filter papers in $10 \%$ buffered formalin for the first $12 \mathrm{~h}$ and then $80 \%$ ethanol, and coded for blind scoring.

Quantification of ACF. Morphometric analysis of the colonic mucosa was done according to Bird (25) and is routinely performed in our laboratory (26). After a minimum of $24 \mathrm{~h}$, fixed colons were stained with $0.2 \%$ methylene blue solution for 5-10 min, placed mucosal side up on a microscopic slide, and viewed under a light microscope. The total number of $\mathrm{ACF}$ in the entire colon was determined in every $2-\mathrm{cm}$ section of the colon, starting from the distal (taken as $0 \mathrm{~cm}$ ) to the proximal end of the colon. Aberrant crypts were distinguished from surrounding normal crypts by their increased size, increased distance from lamina to basal surfaces of cells, and easily discernible pericryptal zone. The parameters used to assess the aberrant crypts were incidence and multiplicity. Aberrant crypt multiplicity was determined as the number of crypts in each focus and categorized as containing $\geq 4$ aberrant crypts/ focus.

In vitro studies: Materials. Protease inhibitor cocktail was purchased from Sigma (St. Louis, MO). Antibodies p21, survivin, cyclin A, Bcl-2, and Bcl- $\mathrm{X}_{\mathrm{L}}$, were purchased from Santa Cruz Biotechnology (Santa Cruz, CA). Actin was purchased from Cell Signaling (Danvers, MA).

Cell culture. The human colon cancer cell line HCT-116 obtained from the American Type Culture Collection (Manassas, VA) and HCA-7 cells were maintained in McCoy's 5A medium with $10 \%$ fetal bovine serum with $5 \% \mathrm{CO}_{2}$ at $37^{\circ} \mathrm{C}$. All experiments were carried out with cells grown to $\sim 70-80 \%$ confluence in cultured medium. All experiments were performed in unbuffered medium (without sodium bicarbonate). Stock solution of omeprazole was prepared by solubilizing $100 \mathrm{mg}$ of omeprazole in $10 \mathrm{ml}$ of DMSO. Cells were treated with various concentrations of omeprazole solution or equal volume of DMSO as a vehicle.

Treatment of cells. To assess growth inhibition, apoptosis, and molecular markers, we applied various subtoxic dose levels of omeprazole, ranging from 0 to $300 \mu \mathrm{M}$ for $24 \mathrm{~h}$. After $24 \mathrm{~h}$ of treatment with omeprazole, cells were harvested and lysates were prepared and stored at $-80^{\circ} \mathrm{C}$ for evaluating different molecular markers.

Cell viability and cytotoxicity assays. Cell viability was determined by the Trypan blue dye exclusion method and cytotoxicity was assessed by MTT (3-[4,5-dimetylthiazole2-yl]-2,5-diphenyl tetrazoliumbromide) assay. Exponentially growing cells $\left(1 \times 10^{4}\right)$ were cultured overnight in 96-well plates containing McCoy's 5A medium and incubated overnight. The next day, cells were treated with a series of different omeprazole concentrations $(0-600 \mu \mathrm{m})$ for $24 \mathrm{~h}$. Each concentration was repeated in 3 wells, after incubation for $24 \mathrm{~h}$ with the drug at $37^{\circ} \mathrm{C}$ in a humidified incubator. For cytotoxicity, $20 \mu \mathrm{l}$ of MTT (5 $\mathrm{mg} / \mathrm{ml}$ stock solution) solution was added to each well and incubated for $4 \mathrm{~h}$ at $37^{\circ} \mathrm{C}$. MTT was then removed from the wells by aspiration. After careful removal of the MTT solution, $0.1 \mathrm{ml}$ of DMSO was added to each well and plates were shaken to dissolve the purple formazan crystals. The absorbance was recorded on a microplate reader at the wavelength of $570 \mathrm{~nm}$ using BMG LabTech spectrophotometer (BMG LabTech Inc., Cary, NC). The data were normalized to respective control and expressed as a percentage of viable cells.

For the trypan blue exclusion method, HCA-7 and HCT-116 cells were seeded in six-well culture plates, treated with different omeprazole concentrations $(0-600 \mu \mathrm{M})$ and incubated 
<smiles>COc1ccc2[nH]c(S(=O)Cc3ncc(C)c(OC)c3C)nc2c1</smiles>

Figure 1. Structure of omeprazole.

for $6,12,24$, and $48 \mathrm{~h}$. At each point, cells were washed with PBS and trypsinized. Cell suspension (100 $\mu \mathrm{l})$ were mixed with $100 \mu$ l of trypan blue dye ( $0.4 \%$ trypan blue in saline), a small aliquot was applied to a hemocytometer, and live cells were counted, utilizing the cover slip. The effect on cell growth inhibition was assessed as percent cell viability where vehicle treated cells were taken as $100 \%$ viable (data not shown).

Apoptosis assay by acridine orange/ethidium bromide staining. Exponentially growing $\mathrm{HCA}-7$ cancer cells $\left(1 \times 10^{4}\right)$ were cultured overnight in 6-well plates containing McCoy's 5A medium and treated with various concentrations of omeprazole for $24 \mathrm{~h}$. After trypsinization $25 \mu \mathrm{l}$ of the cell suspension $\left(\sim 3 \times 10^{4}\right.$ per $\left.\mathrm{ml}\right)$ were incubated with $1 \mu \mathrm{l}$ of acridine orange/ ethidium bromide (one part each of $100 \mu \mathrm{g} / \mathrm{ml}$ acridine orange and $100 \mu \mathrm{g} / \mathrm{ml}$ ethidium bromide in PBS). A $10 \mu \mathrm{l}$ aliquot of the gently mixed suspension was placed on microscope slides, covered with coverslips, and examined under an Olympus AX70 microscope (Tokyo, Japan) connected to a digital imaging system with SPOT RT software version 3.0. Acridine orange is a vital dye that will stain both live and dead cells, whereas ethidium bromide will stain only those cells that have lost their membrane integrity.

Western blot analysis. Cells exposed to omeprazole were lysed in ice-cold lysis buffer [50 mmol/1 Tris ( $\mathrm{pH} \mathrm{7.4),} 150 \mathrm{mmol} / 1$ $\mathrm{NaCl}, 1 \mathrm{mmol} / \mathrm{l}$ EDTA, $1 \% \mathrm{NP} 40,50 \mathrm{mmol} / \mathrm{l} \mathrm{NaF}, 1 \mathrm{mmol} / 1$ sodium orthovanadate, $1 \mathrm{mmol} / 1$ phenylmethylsulfonyl fluoride, $1 \mathrm{mmol} / \mathrm{l} \mathrm{DTT}$, and protease inhibitor cocktail] and the protein content was determined by Bio-Rad Protein Assay reagent (Hercules, CA). Separation of proteins $(50 \mu \mathrm{g})$ was resolved on an SDS-PAGE and transferred onto nitrocellulose membranes. Membranes were blocked with a solution containing $10 \mathrm{mmol} / \mathrm{l}$ Tris- $\mathrm{HCl}$ (pH 7.5), $150 \mathrm{mmol} / \mathrm{l} \mathrm{NaCl}, 0.01 \%$ (v/v) Tween-20 and 5\% dry milk, and incubated overnight with either anti-p21 (1:250), anti-survivin (1:100), anti-cyclin A $(1: 1,000)$, anti-Bcl$\mathrm{X}_{\mathrm{L}}$ (1:200), anti-Bcl-2 (1:500), anti-Cox-2 (1:100), or anti-actin $(1: 1,000)$. After washing with TBST blots were incubated with anti-mouse, anti-goat, and rabbit horseradish peroxidaseconjugated secondary antibody corresponding with respect to primary antibody followed by washing with TBST. Blots were incubated with Super Signal West Pico Chemiluminescence Substrate (Pierce, Rockford, IL) for $5 \mathrm{~min}$ and exposed to Kodak film.

Statistical analysis. Data values were expressed as the mean \pm SE. Statistical significance was determined by the one-tailed

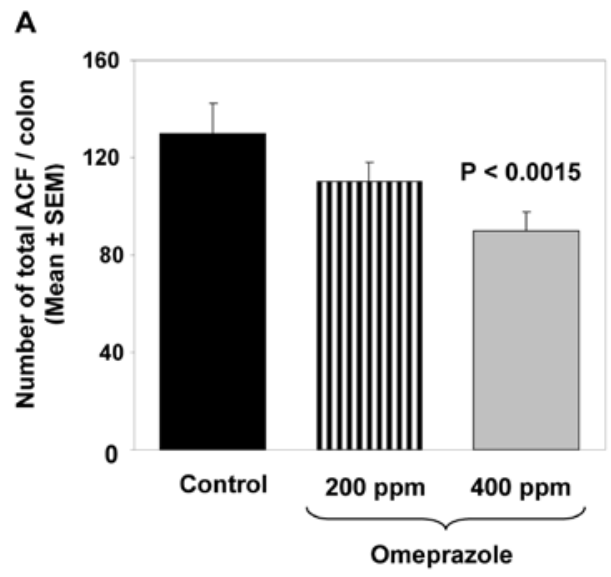

B

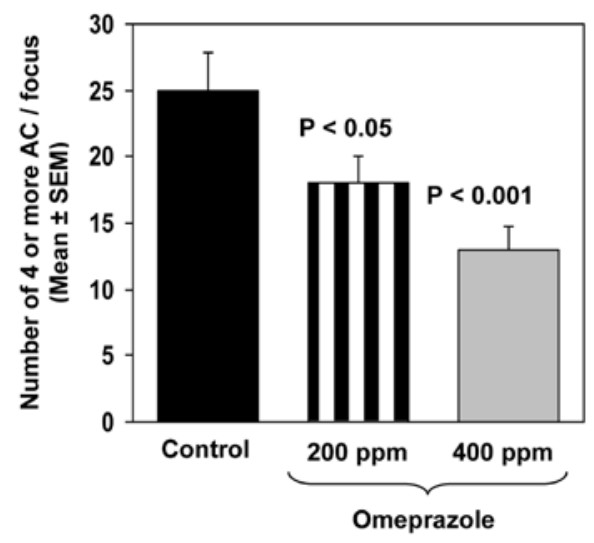

Figure 2. Preventive effect of omeprazole on AOM-induced colonic total aberrant crypt foci in F344 rats (A). Preventive effect of omeprazole on AOM-induced colonic $\geq 4$ aberrant crypts in F344 rats (B).

unpaired t-test with Welch's correction. Differences were considered statistically significant at $\mathrm{P}<0.05$.

\section{Results}

Effect of omeprazole on carcinogen-induced colonic ACF formation. As shown in Fig. 2A, omeprazole at 200 ppm and $400 \mathrm{ppm}$ given in the diet showed a suppression of total colonic ACF by $\sim 15$ and $30 \%(\mathrm{P}<0.0015)$, respectively, compared with the control group. As shown in Fig. 2B, dietary administration of 200 and 400 ppm omeprazole significantly suppressed large foci formation (with crypt multiplicity of $\geq 4)$ to $28 \%(\mathrm{P}<0.05)$ and $44 \%(\mathrm{P}<0.001)$, respectively. Omeprazole inhibited the AOM-induced colonic foci containing $\geq 4$ aberrant crypts in a dose-dependent manner $(\mathrm{P}<0.001)$.

Omeprazole inhibits the proliferation of HCA-7 and HCT-116 colon cancer cell lines. To explore the effect of omeprazole on human colon cancer cells, we treated HCA-7 and HCT-116 human colon cancer cells with increasing concentrations of omeprazole for $24 \mathrm{~h}$ and cell survival was assessed by an MTT assay. As shown in Fig. 3A, a significant loss of viability was detected in both cell lines at 100, 200, 300 and $400 \mu \mathrm{M}$ of omeprazole in a dose-dependent manner with an $\mathrm{IC}_{50}$ value of $250 \mu \mathrm{M}$ at $24 \mathrm{~h}$. Cell growth inhibition by omeprazole was further confirmed using the trypan blue dye exclusion method 
A

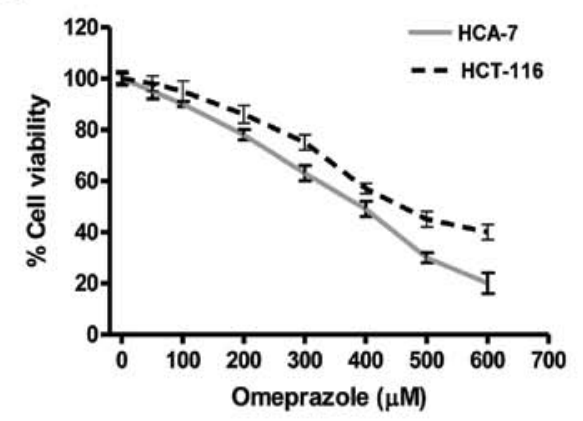

B
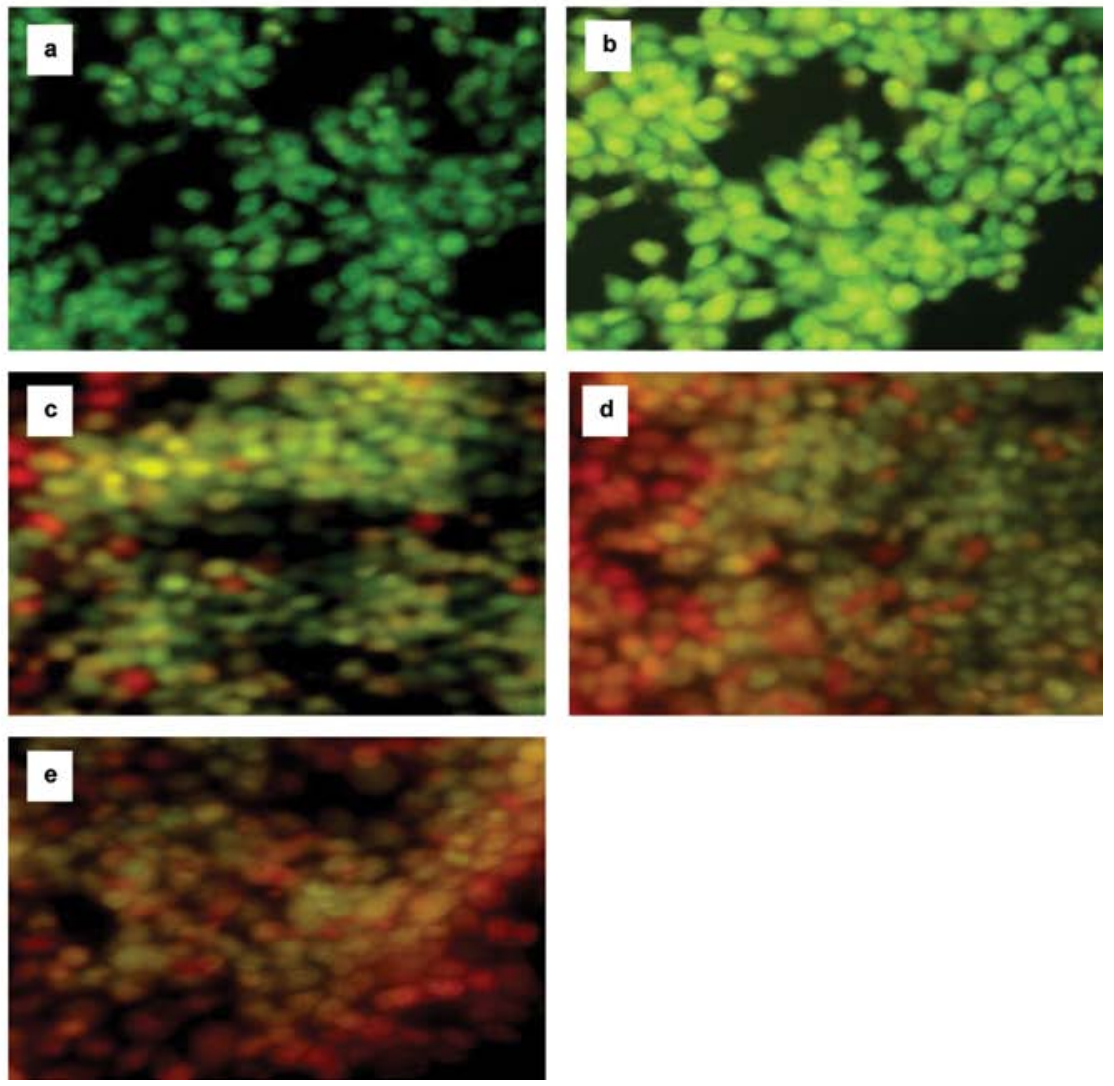

Figure 3. Effect of omeprazole on viability of human colon cancer cells (HCT-116 and HCA-7) (A); cells were treated with specified concentrations of omeprazole for $24 \mathrm{~h}$, and cell viability was determined by MTT assay. Each concentration of omeprazole was repeated in three wells. The values are represented as the percent viable cells where vehicle-treated cells were regarded as $100 \%$ viable. Data represent mean value of percent viable cells \pm SE of three independent experiments. The details are described in Materials and methods. Acridine orange/ethidium bromide staining of HCA-7 cells to detect apoptosis induced by different concentrations of omeprazole for $24 \mathrm{~h}$ (\% apoptosis) (B): $0 \mu \mathrm{M} / \mathrm{ml}$ (0.2\%) (a), $50 \mu \mathrm{M} / \mathrm{ml}$ (3\%) (b), $100 \mu \mathrm{M} / \mathrm{ml}$ (15\%) (c), 200 $\mu \mathrm{M} / \mathrm{ml}$ (25\%) (d), $300 \mu \mathrm{M} / \mathrm{ml}(35 \%)$ (e). Live cells are uniformly green, whereas apoptotic cells are characterized by orange staining due to chromatin condensation and loss of membrane integrity. Magnification, x200. Triplicate samples were used for each concentration and in each sample, a minimum of 200 cells were analyzed for apoptosis. Data are presented as \% apoptosis.

(data not shown). Twenty-four-hour exposure to omeprazole $(0-600 \mu \mathrm{M} / \mathrm{ml})$ inhibited cell proliferation of HCA-7 and HCT-116 compared with untreated cell growth taken as $0 \%$. This inhibition was $10,22,35,55,70$, and $88 \%$ for 50,100 , $200,300,400$, and $600 \mu \mathrm{M}$ omeprazole, respectively.

Induction of apoptosis by omeprazole. Fig. 3B summarize the effect of omeprazole on induction of apoptosis in HCA-7 colon cancer cells. Apoptotic cells were visualized in terms of characteristic morphologic changes by the acridine orange/ ethidium bromide method. As shown in Fig. 3B, live cells are uniformly stained green and can be distinguished from apoptotic cells (Fig. 3B,c-e) omeprazole at concentrations 50, 100, 200, $300 \mu \mathrm{M}$ induced apoptosis in a dose-dependent manner $(3,15,25$, and $35 \%$, respectively).

Omeprazole induces $p 21^{\text {wafl/cipl }}$ and down regulates the expression of cyclin $A$. We analyzed the expression of cell cycle regulatory proteins in colon cancer cell lines. Omeprazole induced the expression of $\mathrm{p} 21^{\mathrm{waf} 1 / \mathrm{cip} 1}$ in both HCA-7 and 

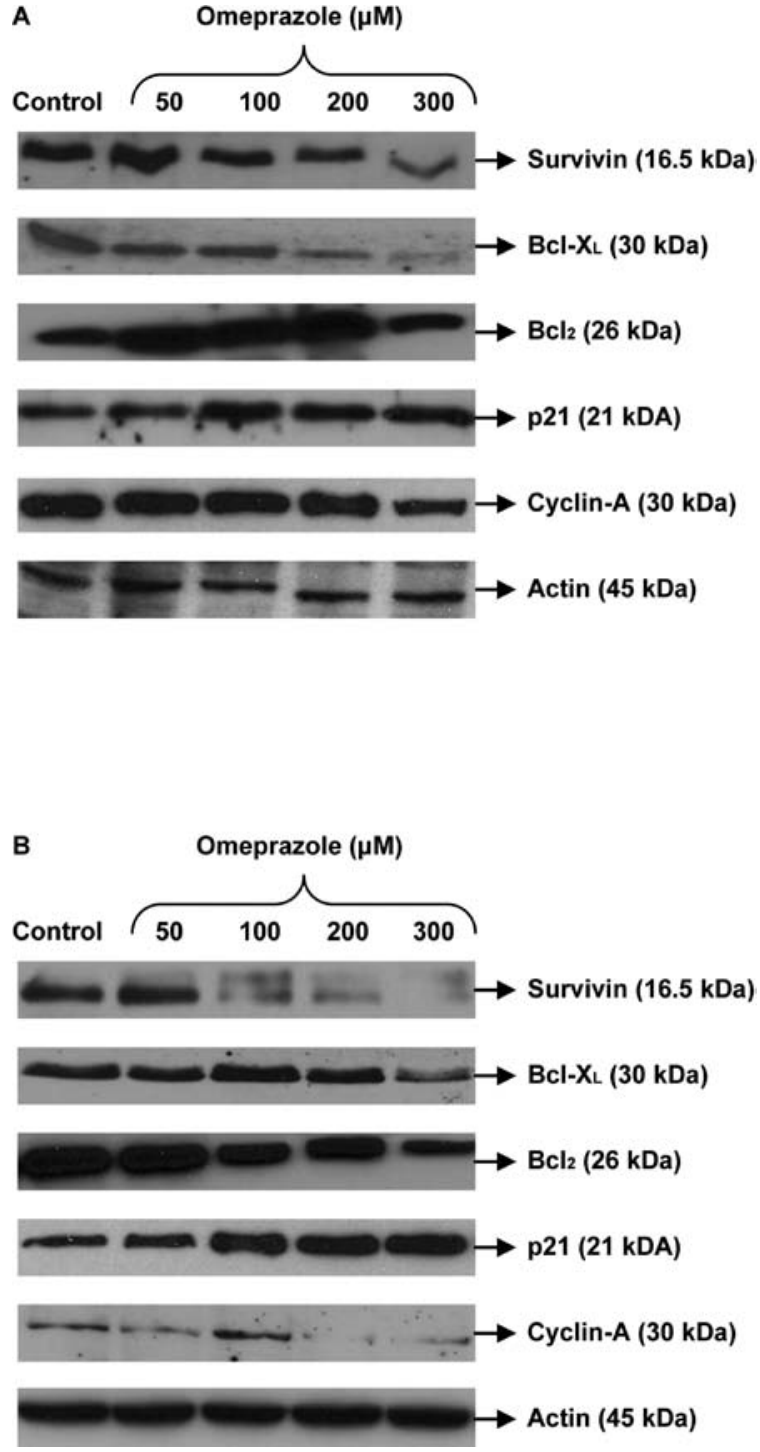

Figure 4. Effect of omeprazole on the protein levels of anti-apoptotic and cell cycle regulatory molecules (A) HCA-7 and (B) HCT-116 human colon cancer cells. Colon cancer cells were treated with different concentrations of omeprazole $(0-300 \mu \mathrm{m} / \mathrm{ml})$ for $24 \mathrm{~h}$ and then harvested. The protein expression of survivin, Bcl- $\mathrm{X}_{\mathrm{L}}, \mathrm{Bcl}-2$, p21 and cyclin A were determined by Western blot analysis. Stripping the membrane and reprobing them for $\beta$-actin confirmed equal loading. The immunoblots shown are representative of three independent experiments with similar results.

HCT-116 colon cancer cells in a dose-dependent manner (Fig. 4A and B). In contrast, cyclin A expression levels were decreased in both HCA-7 and HCT-116 colon cancer cell lines in a dose-dependent manner (Fig. 4A and B).

Effect of omeprazole on the expression levels of anti-apoptotic proteins $B c l-2, B c l-X_{L}$ and survivin. To explore the possible role of Bcl-2 family members in omeprazole-induced apoptosis, we examined the effects of omeprazole on expression levels of Bcl-2 members by Western blot analysis. Exposure of HCA-7 and HCT-116 colon cancer cells with various omeprazole concentrations $(0-300 \mu \mathrm{M})$ for $24 \mathrm{~h}$ resulted in down-regulation of Bcl- $\mathrm{X}_{\mathrm{L}}$ and Bcl-2 expression as shown in Fig. 4A and B. In addition, survivin, a mitochondrial bound protein and an anti-apoptotic signaling protein, which regulates apoptosis is a highly expressed in untreated cells suggesting critical signaling protein in colon cancer cell survival $(22,23)$. Whereas, colon cancer cells treated with omeprazole showed significantly down-regulation of survivin.

\section{Discussion}

The major objective of this study was to test chemopreventive and anticancer effects of omeprazole in colon carcinogenesis. Administration of omeprazole in the diet significantly reduced AOM-induced total colonic ACF formation and multi-crypt aberrant crypt foci growth. To date, this is the first study to show inhibition of colonic ACF, which mimics the pathological precursor lesions of human sporadic colon cancer and widely used animal models of colon cancer chemoprevention studies (25-27). Previous studies have established that ACF containing $\geq 4$ aberrant crypts correlates with colon tumor outcome. Importantly, dietary omeprazole administration at 200 and 400 ppm significantly suppressed large foci formation by $28 \%(\mathrm{P}<0.05)$ and $44 \%(\mathrm{P}<0.001)$, respectively, in a dose-dependent manner. The results further support previous observations of inhibition of colon tumor incidence $(37 \%)$ and multiplicity $(\sim 50 \%)$ in Sprague-Dawley rats by chronic omeprazole $(40 \mu \mathrm{mol} / \mathrm{kg})$ treatment. In another study, by Kim et al (11), omeprazole treatment resulted in reduced number of tumors in colitis-induced carcinogenesis in mice. Overall, use of sporadic colorectal cancer F344 rat model (27) which develops ACF-adenoma-carcinoma sequence that mimics human colon tumor development is justified in further development of omeprazole and other PPI for colon cancer prevention.

Our results suggest that omeprazole suppresses cell proliferation and induces apoptosis in a dose-dependent manner in colon cancer cells. As shown in Fig. 4A and B, we observed that there was an induction of $\mathrm{Cdk}$ inhibitor $\mathrm{p} 21^{\text {waf } 1 / \mathrm{cip} 1}$ with an associated decrease in the expression of cyclin $\mathrm{A}$, which is consistent with previous studies where induction of $\mathrm{p} 21^{\text {waf } 1 / \text { cip } 1}$ leads to $\mathrm{Cdk} 2$ binding at amino acid residues (amino acids $139-164)$, which is required by cyclin A complex $(28,29)$. Thus, omeprazole may directly induce $\mathrm{p} 21^{\text {waf } 1 / \mathrm{cip} 1}$, which leads to inhibition of $\mathrm{Cdk} 2$ complex formation with cyclin $\mathrm{A}$, reduces levels of cyclin A, and limits the Cdk2 complex leading to growth arrest.

Members of the Bcl-2 protein family are associated with the mitochondrial membrane and have regulated membrane integrity (14). It is the ratio of anti-apoptotic $\left(\mathrm{Bcl}-2, \mathrm{Bcl}-\mathrm{X}_{\mathrm{L}}\right)$ to pro-apoptotic (Bim, Bad, Bax, Bak) molecules that sets the threshold of susceptibility to apoptosis $(14,30)$. Bcl-2, Bcl-X and anti-apoptotic proteins seem to dimerize with a proapoptotic molecule Bax and modulate the sensitivity of cells to apoptosis (31). Omeprazole treatment decreased the levels of the anti-apoptotic proteins $\mathrm{Bcl}-2$ and $\mathrm{Bcl}-\mathrm{X}_{\mathrm{L}}$ in a dose-dependent manner. In addition to $\mathrm{Bcl}-2$ and $\mathrm{Bcl}-\mathrm{X}_{\mathrm{L}}$, we tested caspase- 3 cleavage but did not find any changes in caspase- 3 in contrast to earlier findings reported by Scaringi in Jurkat cells (32) and also by Kim et al (11) in animal models. In general, Bcl-2 and Bcl- $\mathrm{X}_{\mathrm{L}}$ appear to control cell survival by inhibiting the intrinsic apoptotic pathway, which is regulated by a mitochondrial pathway, cytochrome $\mathrm{C}$ release, and mediated by caspase- 9 , caspase- 3 cleavage (30). However, omeprazole is able to induce apoptosis by inhibiting $\mathrm{Bcl}-2$ and $\mathrm{Bcl}-\mathrm{X}_{\mathrm{L}}$ independently of caspase- 3 
cleavage, suggesting a mechanism that is independent of cytochromeC/Apaf-1/caspase-9 pathway (33).

In the present study omeprazole down-regulated the survivin expression, which is an important anti-apoptotic IAP protein widely expressed in human colorectal cancer (21-23). It is well known that mutations in APC and $\beta$-catenin are common in CRC $(34,35)$ and result in aberrant gene expression of oncogenes in which survivin is a downstream target gene (35). However, the process in which omeprazole regulates survivin expression in human colon cancer cells warrants further investigation.

In summary, in vivo efficacy studies suggest that dietary omeprazole inhibits chemically-induced colon carcinogenesis in rats and our in vitro data indicate that omeprazole inhibits HCT-116 and HCA-7 colon cancer cell proliferation and induce apoptosis by inducing p21 and suppressing cyclin A, survivin and anti-apoptotic proteins $\mathrm{Bcl}-2$ and $\mathrm{Bcl}-\mathrm{X}_{\mathrm{L}}$.

\section{Acknowledgements}

This study was supported in part by USPHS Grants NO1-CN53300 from the NCI. We wish to thank Ashley for her help in the editing and preparation of this manuscript.

\section{References}

1. Jemal A, Siegel R, Xu J and Ward E: Cancer Statistics, 2010. CA Cancer J Clin 60: 277-300, 2010.

2. Der G: An overview of proton pump inhibitors. Gastroenterol Nurs 26: 182-190, 2003

3. Martin de Argila C: Safety of potent gastric acid inhibition. Drugs 65: 97-104, 2005.

4. De Milito A, Iessi E, Logozzi M, et al: Proton pump inhibitors induce apoptosis of human B-cell tumors through a caspaseindependent mechanism involving reactive oxygen species. Cancer Res 67: 5408-5417, 2007.

5. Marino ML, Fais S, Djavaheri-Mergny M, et al: Proton pump inhibition induces autophagy as a survival mechanism following oxidative stress in human melanoma cells. Cell Death Dis 1: e87, 2010.

6. Yeo M, Kim DK, Kim YB, et al: Selective induction of apoptosis with proton pump inhibitor in gastric cancer cells. Clin Cancer Res 10: 8687-8696, 2004

7. Tobi M, Chintalapani S, Goo R, et al: Omeprazole inhibits growth of cancer cell line of colonic origin. Dig Dis Sci 40: $1526-1530,1995$

8. Tagaki T, Naito Y, Okada H, et al: Lansoprazole, a proton pump inhibitor, mediates anti-inflammatory effect in gastric mucosal cells through the induction of heme oxidase-1 via activation of NF-E2-related factor 2 and oxidation of Kelch-like ECH-associated protein 1. J Pharmacol Exp Ther 331: 255-264, 2009.

9. Becker JC, Grosser N, Waltke C, et al: Beyond gastric acid reduction: proton pump inhibitors induce heme oxigenase-1 in gastric and endothelial cells. Biochem Biophys Res Commun 345: 1014-1021, 2006

10. Penman ID, el-Omar E, McGregor JR, Hillan KJ, O'Dwyer PJ and McColl KE: Omeprazole inhibits colorectal carcinogenesis induced by azoxymethane in rats. Gut 34: 1559-1565, 1993 .

11. Kim YJ, Lee JS, Hong KS, Chung JW, Kim JH and Hahm KB Novel application of proton pump inhibitor for the prevention of colitis-induced colorectal carcinogenesis beyond acid suppression. Cancer Prev Res (Phila) 3: 963-974, 2010.

12. Hurwitz A, Sztern MI, Looney GA, Pinson DM, Bauer KD and Kimler BF: Effects of omeprazole on cell kinetics of carcinogeninduced colon tumors in rats. Cell Prolif 28: 525-531, 1995.
13. Pinson DM, Havu N, Sztern MI, Mattsson H, Looney GA, Kimler BF and Hurwitz A: Drug-induced hypergastrinemia: absence of trophic effects on colonic carcinoma in rats. Gastroenterology 108: 1068-1074, 1995.

14. Adams JM and Cory S: The Bcl-2 protein family: arbiters of cell survival. Science 281: 1322-1326, 1998

15. Gross A, McDonnell JM and Korsmeyer SJ: BCL-2 family members and the mitochondria in apoptosis. Genes Dev 13: 1899-1911, 1999.

16. Deveraux QL and Reed JC: IAP family proteins: suppressors of apoptosis. Genes Dev 13: 239-252, 1999.

17. Salvesen GS and Duckett CS: IAP proteins: blocking the road to death's door. Nat Mol Cell Biol 3: 401-410, 2002.

18. Tamm I, Wang Y, Sausville E, Scudiero DA, Vigna N, Olsterdorf T and Reed JC: IAP-family protein survivin inhibits caspase activity and apoptosis induced by Fas (CD95), Bax, caspases, and anticancer drugs. Cancer Res 58: 5315-5320, 1998.

19. Altieri DC: Validating survivin as a cancer therapeutic target. Nat Rev Cancer 3: 46-54, 2003.

20. Ambrosini G, Adida C and Altieri DC: A novel anti-apoptosis gene, survivin expressed in cancer and Lymphoma. Nat Med 3: 917-921, 1997.

21. Kawasaki H, Altieri DC, Lu CD, Toyoda M, Tenjo T and Tanigawa N: Inhibition of apoptosis by survivin predicts shorter survival rates in colorectal cancer. Cancer Res 58: 5071-5074, 1998.

22. Gianani R, Jarboe E, Orlicky D, Frost M, Bobak J, Lehner R and Shroyer KR: Expression of survivin in normal, hyperplastic, and neoplastic colonic mucosa. Hum Pathol 32: 119-125, 2001.

23. Kim PJ, Plescia J, Clevers H, Fearon ER and Altieri DC: Survivin and molecular pathogenesis of colorectal cancer. Lancet 362: 205-209, 2003.

24. American Institute of Nutrition: Report of the American Institute of Nutrition ad hoc committee on standards for nutritional studies. J Nutr 107: 1340-1348, 1977.

25. Bird RP: Observation and quantification of aberrant crypts in the murine colon treated with a colon carcinogen: preliminary findings. Cancer Lett 37: 147-151, 1987.

26. Patlolla JM, Raju J, Swamy MV and Rao CV: Beta-escin inhibits colonic aberrant crypt foci formation in rats and regulates the cell cycle growth by inducing $\mathrm{p} 21^{\text {waf } 1 / \text { cipl }}$ in colon cancer cells. Mol Cancer Ther 5: 1459-1466, 2006.

27. Rosenberg DW, Giardina C and Tanaka T: Mouse models for the study of colon carcinogenesis. Carcinogenesis 30: 183-196, 2009.

28. Mutoh M, Lung FD, Long YQ, Roller RP, Sikorski RS and O'Connor PMA: p21(Waf1/Cip1) carboxy-terminal peptide exhibited cyclin-dependent kinase-inhibitory activity and cytotoxicity when introduced into human cells. Cancer Res 59: 3480-3488, 1999

29. Cai K and Dynlacht BD: Activity and nature of $\mathrm{p} 21^{\mathrm{WAFl} / \mathrm{CIP} 1}$ complexes during the cell cycle. Proc Natl Acad Sci USA 95: 12254-12259, 1998.

30. Youle RJ and Strasser A: The BCL-2 protein family: opposing activities that mediate cell death. Nat Rev Mol Cell Biol 9: 47-59, 2008.

31. Pastorino JG, Chen ST, Tafani M, Snyder JW and Farber JL: The over expression of Baxproduces cell death upon induction of the mitochondrial permeability transition. J Biol Chem 273: 7770-7775, 1998.

32. Scaringi L, Cornacchione P, Ayroldi E, Corazzi L, Capodicasa E, Rossi R and Marconi P: Omeprazole induces apoptosis in jurkat cells. Int J Immunopathol Pharmacol 17: 331-342, 2004.

33. Marsden VS, O'Connor L, O'Reilly LA, et al: Apoptosis initiated by $\mathrm{Bcl}-2$ regulated caspase activation independently of the cytochrome c/Apaf-1/caspase-9 apoptosome. Nature 419: 634-637, 2002.

34. Zhang T, Otevrel T, Gao Z, et al: Evidence that APC regulates survivin expression: a possible mechanism contributing to the stem cell origin of colon cancer. Cancer Res 61: 8664-8667, 2001.

35. Li H, Pamukcu R and Thompson WJ: beta-Catenin signaling: therapeutic strategies in oncology. Cancer Biol Ther 1: 621-625, 2002. 